\title{
Impact of Digitalization in Business World
}

Magdalena Alina ILCUS ${ }^{1}$

Abstract
Digitalization is in every field of our lives: education and schools, social
networking, in business, as almost each company has a website and in business
processes: marketplaces, logistics, and more and more, in accounting. Consequently, the
current age became "digital era".
Digital technology allows making tasks faster and more accurate. That's why,
its growth impacts digital marketplace and continues to grow each and every year:
Amazon, Alibaba, Ebay, Emag, Olx. Digital networking is developing fast too: Facebook,
Instagram, Twitter, Pinterest, LinkedIn.
This article focuses on being digital issue in the business world by presenting
some of its advantages and why it is important going digital for companies.
accounting

Keywords: digitalization, digital markets, technological change, finance and

JEL classification: F64, F65, F66, O33

DOI: $10.24818 / \mathrm{RMCI} .2018 .4 .350$

\section{Introduction}

In this paper we will analyze the impact of digitalization in the business world, as we hear about digitalization in everything: education, workplace, networking and business developing.

In this context of speedy development of digital technologies, businesses may choose to engage in innovation strategies and rethink operation models. Therefore, impact of digitalization in business processes seems to become an actual topic of the management focus.

In the end of the paper we present an insight of future technological change consequences in finance and accounting field.

\section{Issue of Digitalization}

Digitalization simply means the conversion of analogue information into digital information. (Hughes, 2004, p. 4). In our digital era, virtually every aspect of our life is captured and stored in some digital form. The study of Erst\&Young (E\&Y, 2011, p.2) explains further, that the impact of digitalization is a real-time global exchange of information between multiple connected devices (fixed and mobile).

\footnotetext{
${ }^{1}$ Magdalena Alina Ilcus (Oprisor - Domnariu), 1 Decembrie 1918 University, Alba Iulia, Email: oprisordomnariu@gmail.com
} 
It is important to distinguish between digitalization and digital transformation. To quote Betrand Duperrin, Head of Digital Transformation at Emakina, digitization is "digitizing the existing. Moving from brick and mortar to web. Moving one's customer service online. Turning a paper-based process into a paper-free one."

Digital transformation, on the other hand, is much more than digitalizationit's about changing a company's entire business model, according to Dupperin. Facebook and Skype, Tesla and Airbnb are examples of companies that were able to successfully execute digital transformation in a way that presented an entirely new business model to the telecommunication, hotel and respectively automobile industry.

Regarding technology adoption, as we may see in the figure bottom, cell phones and internet experience high rates, as never ever again in the last 120 years. The digital natives as defined by John Palfrey and Uri Gasse, 'Born Digital', "were all born after 1980 when social digital technologies became widely used; they all have access to networked digital technologies and they have the skills to use these."

Theses digital natives are called in the Ernst\&Young study, the YGeneration (p.5) and represents over a quarter of the world's population. It is no longer content with the old corporate and political model. They seek transformational change, and where they cannot find it, they look to invent it themselves.

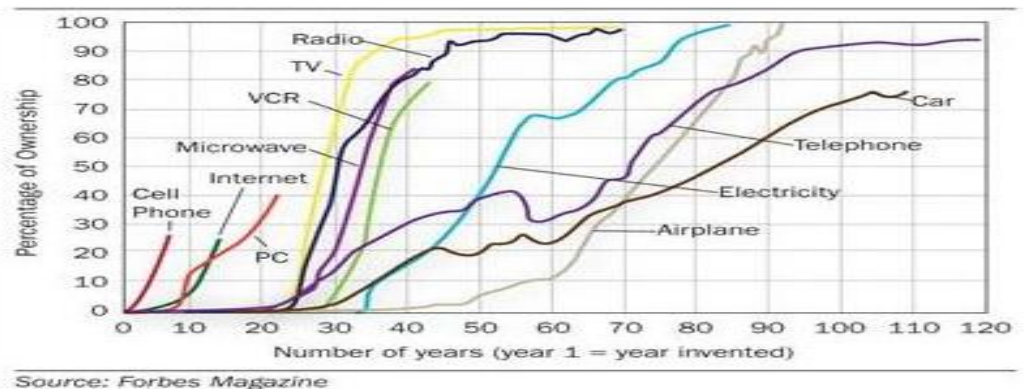

Figure 1. Technology Adoption

Available at https://techliberation.com/2009/05/28/on-measuring-technology-diffusionrates/ [accessed 11 April ]

The evolving expectation of these generation is challenging the companies to face the implication of digital change. The need to engage digitally with suppliers, employees and in addition to customers is fast growing. Companies are losing monopoly due to speedy spreading of information, because customers gain more power to choose, where and how they interact.

\section{Digital Transformation}

A new kind of consumer means new ways of doing business. For better customer relation and satisfaction, companies are using different platform of 
digitalization. Today, most companies are either thinking about or pressing ahead with digital transformation initiatives. Every company has a website, and few marketing strategies are signed off without incorporating social media. Certainly, social media is a critical component of any digital strategy, but a holistic response to the digital shift must go much further. (Ruth Rikowski, 2011)

Goldman Sachs study shows its assumption on the market grow up to year 2025, being a kind of alarm for our preparation for the future. As $80 \%$ of jobs will involve digitalization until 2020 , there is no excuse for the companies to delay the digitalization of processes.

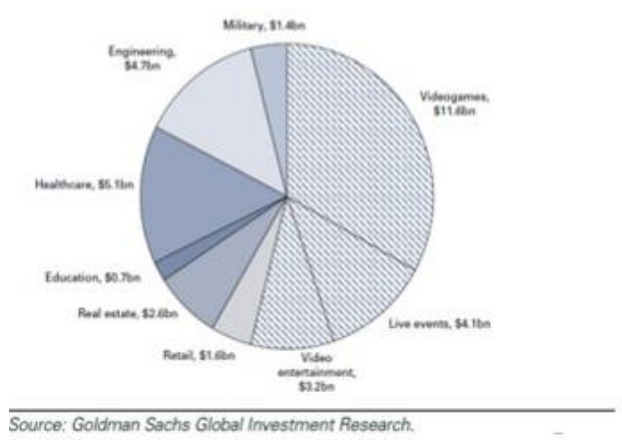

\begin{tabular}{|l|r|}
\hline Video games & $\$ 11.6 \mathrm{bn}$ \\
\hline Healthcare & $\$ 5.1 \mathrm{bn}$ \\
\hline Engineering & $\$ 4.7 \mathrm{bn}$ \\
\hline Live events & $\$ 4.1 \mathrm{bn}$ \\
\hline Video entertainment & $\$ 3.2 \mathrm{bn}$ \\
\hline Real estate & $\$ 2.6 \mathrm{bn}$ \\
\hline Retail & $\$ 1.6 \mathrm{bn}$ \\
\hline Military & $\$ 1.4 \mathrm{bn}$ \\
\hline Education & $\$ 0.7 \mathrm{bn}$ \\
\hline
\end{tabular}

Figure 2. Evolution of Markets for 2025

Available at https://www.bloomberg.com/news/articles/2016-01-13/goldman-sachs-hasfour-charts-showing-the-huge-potential-in-virtual-and-augmented-reality

[accesed on 11 April]

McKinsey study (2015, P.44) sees benefits to a business in increasing customer engagement and satisfaction, together with the potential to cut operational costs by implementing a digital strategy. Obviously, the complexity of the implementation and the potential cost saving will depend on the size of the business, but it's a safe bet that if you're thinking about this you're ahead of the pack. And bottom line, no matter what the size of your business, it's a safe bet that developing and implementing a digital customer service strategy will result in happier, more satisfied customers, repeat business, referrals, and, of course, growth and profitability. In fact, one of the tenets of McKinsey's piece was that the more digital the journey, the higher the satisfaction. If considered, planned and managed well, business process digitization programs can have a number of benefits for an organization. For example, organizations can:

- improve business process efficiency, quality and consistency

- integrate records with digital systems

- improve accessibility and facilitate better knowledge sharing

- improve response time and client service

- reduce costs 
- promote greater staff flexibility.

- better plan for business continuity.

- and last but not the least is customer satisfaction.

Taking into consideration these huge potential achievements in terms of digital

technologies we may observe they impact the quality of labor, as these actually should support employees' work and more important, these may lead to higher customer satisfaction and in this way, higher turnover.

Digital business models brought enormous benefits: operational efficiency increased, company growth expanded, external and internal communication synchronized, and completely new types of revenue streams appeared.

Figure bottom shows a handful insight of the most significant digital business model inventions of the last decade and the young minds behind these.

Facebook Inc., on the first line bottom, is an American company based in Menlo Park, California. The company includes the social network Facebook, the video \& photo sharing app, Instagram and the messenger WhatsApp. In 2010, the company still had 2,127 employees, with a turnover of 1.97 billion according to Wikipedia. It was founded by Mark Zuckerberg, Eduardo Saverin, Dustin Moskovitz, Andrew McCollum and Chris Hughes- in February 2004, in Cambridge, Massachusetts, United States, but having its central in Menlo Park, California, United States and subsidiaries- WhatsApp Inc.in Onavo.

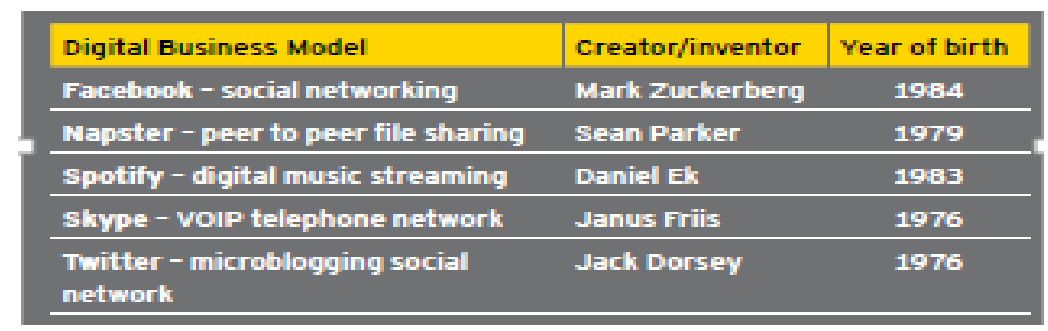

Figure 3. Young Minds behind Digital Business Model Innovation (Erst\&Young Research, p. 5)

In order to reach acceptance for digital transformation or so-called artificial intelligence (AI) implementation, the management should seed trust by defining the ethical principles. According to Christian Kirschniak, Partner and Head of Data \& Analytics Advisory PwC Europe, the message of management should be clear: AI should replace activities, not employees.

\section{Digital Markets}

Most of CEOs in Germany consider that digital transformation will be the competitiv advantage of the future. The PWC study about artificial inteligence (AI) in Germany reveals the following statements in figure bottom. At the present time 
only one of four companies in Germany is using artificial intelligence (AI) in its company in 2018 , according to the bottom given study.

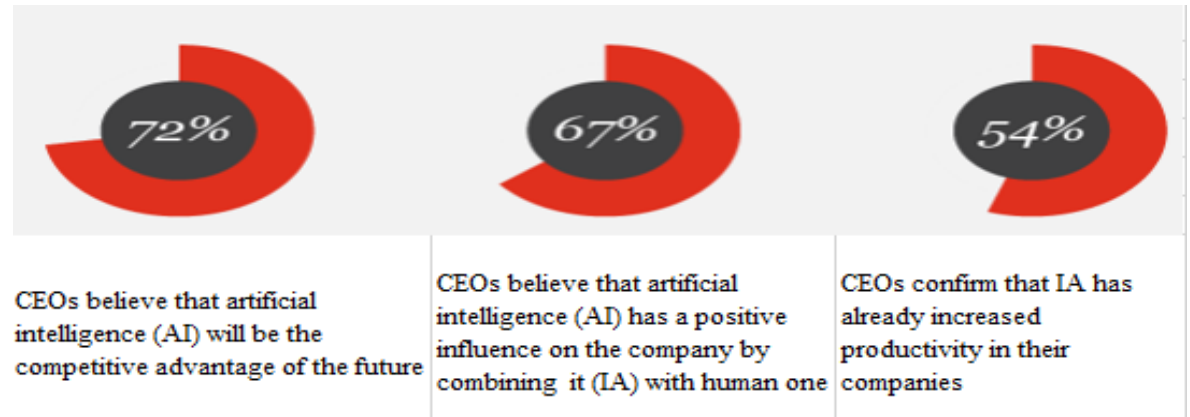

Figure 4. Estimation on AI in Germany, According to PWC Study

Available at: https://www.pwc.de/de/digitale-transformation/der-weg-nach-vorne-ai-alsinnovationsbeschleuniger-in-unternehmen.html

In France digitalization is viewed mainly as an opportunity to prepare the French economy for global competition and to develop into a leading nation. A recent McKinsey study, Accelerating the digital transformation of French businesses: A source of growth and competitiveness for France, finds French companies that have undergone thorough digital transformations may unlock revenue gains of up to 40 percent, while companies that do not quickly become digitally integrated could lose up to 20 percent of revenue to competitors.

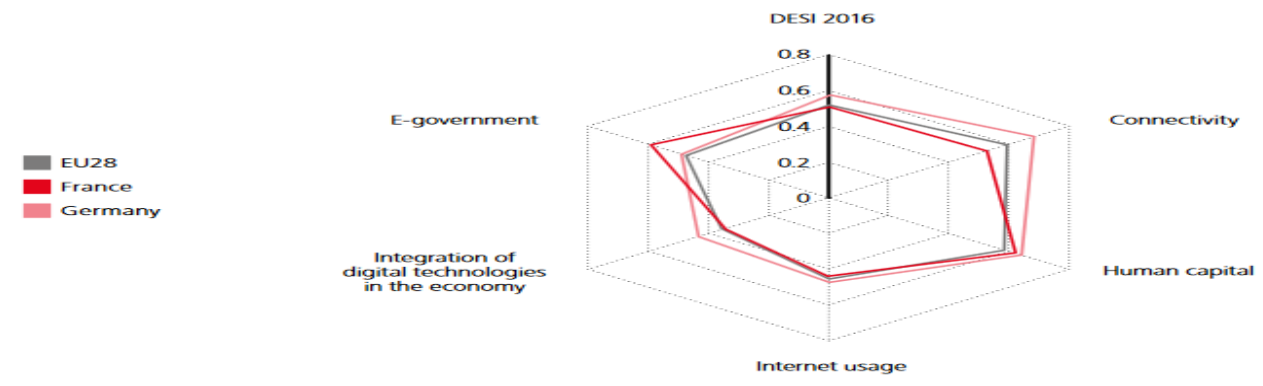

Figure 5. Development of a Digital Society in France by Comparison with Germany and the other $28 \mathrm{EU}$ countries.

Claudia Christ and Rolf Frankenberger, On the Way to Wefare 4.0- Digitalisation in France, Friedrich Ebert Stiftung,

Available at: http://library.fes.de/pdf-files/id/13007.pdf

Digital transformation is one of the cornerstone of France president, Emmanuel Macron, policy. The first page of his Manifesto states that "the digital 
revolution is changing our ways of producing, consuming and living together"(1). The fate of the high-potential technology industry will heavily depend on his ideologies, beliefs, and working style. In his agenda he promised to offer trainings to business leaders and employees to make sure that digital shift take place as soon and smoothly as possible, especially within small and medium enterprises(SMEs) (Etienne 2017).

The legislation background for implementing digital technologies is available in Romania too, beginning with year 2012, according to Law no.148 from 23/0/2012. Apart from archive relating legislation that is available from 1996 with updates in 2006 and 2007, Romanian legislation provides the tools for implementing digital processes. The extend of digital implementation in Romanian companies is seen confidential. Therefore, there are no results of the authors in the conducted survey within this subject- digitalization plans for companies in Romania.

Macroeconomic speaking, digital transformation proofs to be an actual issue in Romania also. SMEs are provided with non-refundable financing possibilities for development of digital businesses from 2017 up to 2020 and for investments in IT equipment.

\section{Impact of Digitalization in Finance and Accounting in German Companies}

The digital revolution is opening up for finance and accounting too, albeit slowly. A survey of the auditing firm PwC shows that only $22 \%$ of the German companies who participated in the survey, use artificial intelligence (AI) in their financial departments. Another $25 \%$ is planning the usage of it. $60 \%$ of decision makers in finance and accounting believe that the artificial intelligence will greatly affect the work in their departments, in the short run to medium term. The overall results of the survey show that financial sectors are opening up to digital technologies such as big data, business analytics, and AI, although many companies are still very cautious about the implementation of these actual developments, according to Petra Justenhoven, member of the board and responsible for the company Auditing department at PwC in Germany.

Renate Sachse from Sachse Fiscal Consultancy in Germany ${ }^{1}$, Chemitz, explains that the digitalization of invoices for ongoing processes in her company is a win to win solution. She implemented electronic invoice sending per email with more than 100 vendors. Furthermore, she presents the following advantages:

- cost savings due to sending electronic invoice cuts printing and paper format mail costs

- better control of invoices

- legal fulfillment of archive obligation

- $\quad$ quicker processes with lower efforts and lower costs 
The implementing of digitalization brings more flexibility that leads to developing Shared Service Centers (SSCs) mainly for activities with a high rate of repetition.

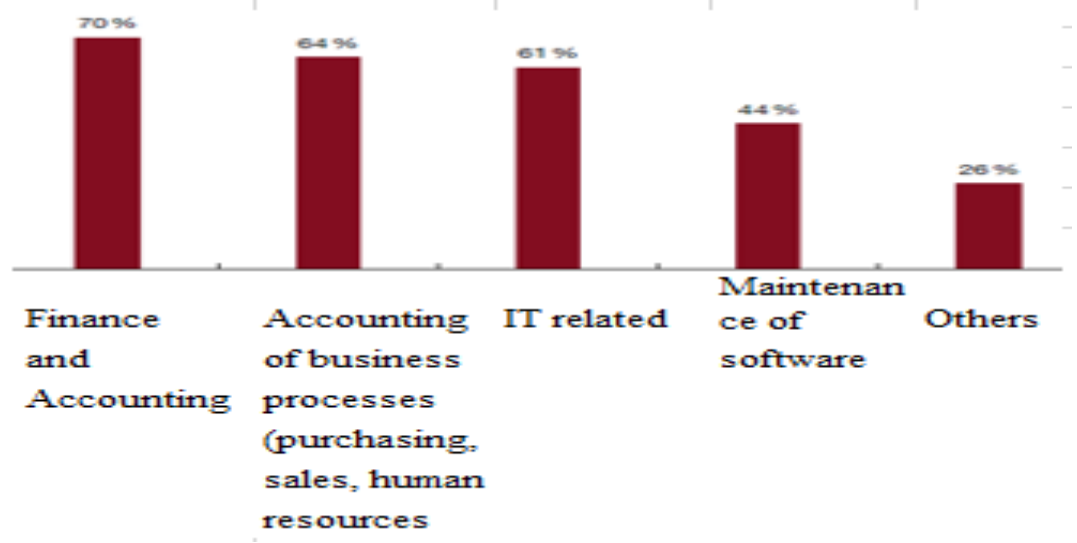

Figure 6. Functions of SSCs According to PWC Study

$70 \%$ to SSC outsourced activities are in field of finance and accounting, according to the PWC Study. From outsourced activities the first ones are accounts payable and accounts receivable. More than half (60\%) of the big German companies, from which most of them with activities over 10 countries use at least one SSC for finance and accounting. One third of these SSCs are located in Germany and abroad.

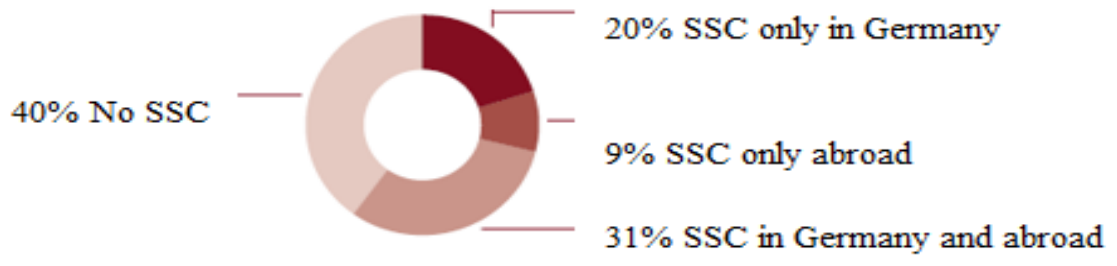

Figure7. Use of SSCs of German big Companies According to PWC Study

Outsourcing a department's activities abroad is only possible in the context of high digital technologies, that allow electronic data manipulation. Furthermore, it needs to provide confidence in IT relating digital technologies according to internal data protection and confidentiality. 


\section{Conclusions}

The above presented advantages of implementing digital technologies should be a driver for building up a future competitive advantage for business world counterparts. Understanding the need is the first step in building customer relations and ethical principles for employees. The implementing of digitalization today may build a strategic advantage for the future, that may leave competition far behind.

\section{References}

Bloomberg News, Goldman-sachs-has-four-charts-showing-the-huge-potential-invirtual-and-augmented-reality, Available at: https://www.bloomberg.com/ news/articles/2016-01-13/goldman-sachs-has-four-charts-showing-thehuge-potential-in-virtual-and-augmented-reality [accessed 11 April]

Datev Magazin, Digitaler Rechnungsversand fuer alle, 2017 11, Available at: https://www.datev-magazin.de/2017-11/produkte-services-201711/digitaler-rechnungsversand-fuer-alle/, [accessed 11 April]

Datev Magazin, Digitaler Rechnungsversand fuer alle, 2017 11, Available at: https://www.datev-magazin.de/2017-11/produkte-services-201711/digitaler-rechnungsversand-fuer-alle/ Sachse Steuerberatung

Ernst\& Young LLP, 2011, The Digitalisation of Everything, How Organisations must adapt to changing consumer behavior

Etienne Goffin, May 12, 2017, Macron, the President who wants to digitize France, Needle Strategy, Available at: http://needlestrategy.com/2017/05/12/digitalfrench-president-macron/ [accessed 11 April]

Friedrich Ebert Stiftung, Claudia Christ and Rolf Frankenberger, On the Way to Wefare 4.0-Digitalisation in France, Available at: http://library.fes.de/pdffiles/id/13007.pdf [accessed 8 August]

Hughes, Lawerence 2004, Digitizing collections: Strategic issues for the information manager. London: Facet Publishing (Part of Digital Futures Series)

McKinsey Digital, 2015, Industry 4.4, How to navigate digitalization of the manufacturing sector, McKinsey Company [accessed 11 April]

McKinsey study, 2015, Accelerating the digital transformation of French businesses: A source of growth and competitiveness for France, Available at: https://www.mckinsey.com/industries/high-tech/our-insights/closingfrances-100-billion-digital-gap, [accessed 8 August]

Palfrey, John and Gasse, Uri, 2008 'Born Digital'- Understanding the first generation of digital natives, Basic Books

Rikowski, Ruth 2011 Digitalisation Perpectives, Chandos Publishing, Oxford

Presse PWC, Rechnungswesen-oeffnet-sich-fuer-kuenstliche-Intelligenz, 30 Maerz 2017, Düsseldorf, Available at: https://www.pwc.de/de/pressemitteilungen /2017/rechnungswesen-oeffnet-sich-fuer-kuenstliche-intelligenz.html [accessed 11 April] 
PWC Presse, Study digitalisation within financial reporting in Germany, 10. Maerz 2017, Available at: https://www.pwc.de/de/rechnungslegung/studiedigitale-abschlusspruefung.pdf [accessed 11 April]

Presse PWC, Kuenstliche-Intelligenz-Vertrauen-wird-2018-zum-entscheidendenErfolgsfaktor, 28 Dezember 2017, Available at: https://www.pwc.de/ de/pressemitteilungen/2017/kuenstliche-intelligenz-vertrauen-wird-2018zum-entscheidenden-erfolgsfaktor.html [accessed 11 April]

Rechnungswesen-oeffnet-sich-fuer-kuenstliche-Intelligenz, Presse PWC, 30 Maerz 2017, Düsseldorf, Available at: https://www.pwc.de/de/pressemitteilungen /2017/rechnungswesen-oeffnet-sich-fuer-kuenstliche-intelligenz.html [accessed 11 April]

Shepard Home Page, Untapped Potential: France's Digital Transformation of the C-Suite, Available at: https://www.sherpany.com/en/insightsresources/2018/03/23/france-digital-transformation, Home Page Sherpany, Raffael Fiechter, Country Manager at Sherpany in France, MARCH 23, 2018, [accessed 8 August]

Techliberation, Measuring Technology diffusion rates, Available at: https:// techliberation.com/2009/05/28/on-measuring-technology-diffusion-rates/ [accessed 11 April] 